\title{
FISHING IN MEDIEVAL VALENCIA
}

\author{
Frederic Aparisi \\ Universitat de VALÈnCia \\ SPAIN
}

Date of receipt: $23^{\text {rd }}$ of July, 2019

Date of acceptance: $9^{\text {th }}$ of October, 2019

\begin{abstract}
This paper is concerned with fishing in the kingdom of Valencia during the Middle Ages based, mainly, on documentary evidence. Due to features of the sources, it focuses on coastal fishing although it also explores the inland fishing and the existence of fisheries and hatcheries. Although fishing was practised by people from different economic contexts, this paper focused on those that made fishing not their unique but their main professional activity. Through examination of notarial records, local regulations and registries of the court of justice, it analyses fishermen both from a social and an economic perspective. Besides, it deals with the cost of the means of production, trying to stablish how much a boat and the nets costed. Fishing techniques are also studied. An attempt of examining production is made using fish tithe evidence. Consumption is also analysed considering differences among the different social sections but also in accordance with the different religions. Finally, it tackles the trading, the supply and the consumption of fish thanks to urban regulations and tithe, manorial and local custom accounts.
\end{abstract}

\section{KeYwords}

Fishing, Fishermen, Hatcheries, Fish market, Valencia, Rural elites.

\section{Capitalia verba}

Piscatio, Piscatores, Piscatoria, Mercatus piscatorius, Valentia, Aristocratia ruralis. 


\section{Introduction ${ }^{1}$}

During the Middle Ages food system was dominated by cereals and, to a lesser extent, by wine and meat. Fish was in the middle of the food pyramid, consumed during all the year but particularly in Advent and in Lent due to the regulations of the Church that banned adult people from eating meat during these periods. This prohibition made fish a strategic product, not as important as the wheat or the wine, but forced local authorities to guarantee the supply of it especially in those days of abstinence. The kingdom of Valencia, despite having $518 \mathrm{~km}$ of coastline, did not was an exception of this scenario and fishing did not become a mainstay of the local economy.

This article analyses fishing and fishermen of the kingdom of Valencia during the Middle Ages from diverse perspectives but all them based on documentary evidence. Only regarding consumption some existing archaeological evidence has been taken into consideration. As it will be explained, it focuses on sea fishing although some reflexions about lake and rivers fishing will be given. Section 2 analyses fishermen both from a social and an economic point of view. For achieving this, I combine notarial records that included inventories post-mortem, wills and transactions, registries of personal assets and registries of the Court of justice. Section 3 seeks to identify the techniques of fishing used in this area and to measure the costs of the means of production, particularly boats and nets, and how they were managed. In this part, production is also analysed using evidence from the collection of tithes.

Section 4 examines the trading, the supply and the consumption of fish in medieval Valencia. For enquiring into this, I draw on published research, in particular manorial accounts and local regulations from the city of Valencia and from different towns of the kingdom, and notarial records. I examine consumption using toll collections from different towns, household accounts and the few published works with archaeological evidence. Finally, although we have written sources from the right moment of the conquest in the $13^{\text {th }}$ century, most of the evidence used here comes from the $15^{\text {th }}$ century, particularly notarial records, although registries for tithe and local regulations belong mainly to the $14^{\text {th }}$ century.

Medieval fishing has been out of the trending discussions of the Valencian historiography, although it cannot be said that this topic is absolute original. The reason for this marginal importance has to do with the dispersion of evidence and its scarcity, as it will be shown. When medievalists have focused on fish, it has been mostly for studying aspects related to the commerce and the provision of the cities due to those

\footnotetext{
1. Used abbreviations: ACCV, Arxiu del Col-legi del Corpus Christi de València; ACV, Arxiu de la Catedral de València; AHN, Archivo Histórico Nacional; AMAlc, Arxiu Municipal d'Alcoi; ARV, Arxiu del Regne de València. This work falls within the project led by Pere Benito "Mercados y comercialización de vituallas en el Mediterráneo Occidental (siglos XIV-XV). Factores e indicadores de desarrollo e integración regional y suprarregional." (HAR 2016-80298-P), founded by Ministerio de Ciencia, Innovación y Universidades of Spain.
} 
are the topics that more commonly sources show. ${ }^{2}$ Issues such as the standards of living of fishermen or the fishing techniques have remained in a subsidiary place. Furthermore, it has tended to dominate analyses from local and county observatories while studies considering all the Valencian kingdom are quite rare. ${ }^{3}$

As it has been said, the Valencian Country has $518 \mathrm{~km}$ of coastline although it is not absolutely homogeneous. Most of it is dominated by the Gulf of Valencia, a sandy plain with beaches that historically has got shoals of fish away from the coast, particularly large species like tuna. The gulf ends in the Cape de la Nau, in the Midlands. From there, sandy beaches alternate with plunging cliffs originated from Tertiary period. In these parts, shoals come to the coast making its capture easier. Except form these areas, the shoreline is defined by the presence of coastal marshes and lakes. During the Middle Ages, the extension of marshlands and wetlands and the number of lakes were major than in our days. The Albufera - the greatest lake- embraced nearly from the gates of the city of Valencia to the town of Cullera. And there were more lagoons such as the pools of Almenara, Elx and l'Albufereta in Alacant among others. Both in wetlands and in pools, particularly in the Albufera, fishing was an ordinary activity during the medieval period although the documentary evidence of it is quite scarce, except for the Albufera, from which we have some tithe data. Regarding inland fishing, given the Mediterranean pattern of the Valencian rivers, with low water level in summer and torrential risen in Autumn, fishing seems to not be a regular practice. All in all, fishing in medieval Valencia meant basically coastal fishing.

As many other aspects, we know very little about fishing in Valencia before the Christian conquest. The evidence comes from the Christian period. Fishermen and sailors mainly from Catalonia took part in the conquest and colonization of Valencia

2. Igual Luis, David. "El tráfico de pescado en la España meridional y su proyección hacia Italia durante el siglo XV", La pesca nel Lazio. Storia, economia, problemi regionali a confronto, Luigi Parlermo, Donatella Strangio, Manuel Vaquero Piñeiro, eds. Naples: Editoriale Scientifica, 2007: 277-309; Villanueva Morte, Concepción. "El tráfico de pescado en la frontera entre Aragón y Valencia: su intercambio comercial en la aduana de Barracas a mediados del siglo XV", Actas II Simposio de Jóvenes Medievalistas. Lorca 2004, Francisco Jiménez Alcázar, Jorge Ortuño Molina, Leonardo Soler Milla, eds. Murcia: Editum, 2006: 251-270.

3. Aparici Martí, Joaquim. "Hombres de mar en el litoral medieval de la Plana. Vida de los Pescadores", La Mediterrània de la Corona d'Aragó, segles XIII-XVI $i$ VIII centenari de la sentencia arbitral de Torrellas, 1304-2004. XVIII congrés internacional d'història de la Corona d'Aragó, Rafael Narbona Vizcaíno, ed. Valencia: Fundació Jaume II, 2005: 1089-1114; Ayza Roca, Alfred. “La pesca en la València del segle XIV”. L'Espill, 17/18 (1983): 159-180; Hinojosa Montalvo, José R. “Comercio, pesca y sal en el cap de Cerver (Orihuela) en la baja Edad Media". Investigaciones geográficas, 14 (1995): 191-204; Rabassa i Vaquer, Carles. "Funcions econòmiques del port de Peníscola durant la baixa Edat Mitjana", La Mediterrània de la Corona d'Aragó, segles XIII-XVI $i$ VIII centenari de la sentencia arbitral de Torrellas, 1304-2004. XVIII congrés internacional d'història de la Corona d'Aragó, Rafael Narbona Vizcaíno, ed. Valencia: Fundació Jaume II, 2005: 1269-1290; Sánchez Adell, Josep. "La pesca en el Castellón medieval», Boletín de la Sociedad Castellonense de Cultura, 32 (1957): 264-271. For a general analysis see Igual Luis, David. "Pesca y pescadores en el reino de Valencia", Pesci, barche, pescatori nell'area mediterranea dal medioevo all'età contemporanea, Valdo d'Arienzo, Biagio di Salvia, eds. Milan: Franco Angeli, 2010: 68-84; Igual Luis, David. “Proyección marítima y sectores laborales en una ciudad del siglo XV: Valencia, de la pesca a la construcción naval”, El mar vivido. Perfiles sociales de las gentes del mar en la larga duración (siglos XV-XXI), David Igual Luis; María Dolores González Guardiola, eds. Madrid: Ediciones de la Universidad de Castilla la Mancha, 2020: 49-70. For the whole Crown of Aragon, Riera i Melis, Antoni. "La pesca en el Mediterráneo Noroccidental durante la baja edad media", La pesca en la Edad Media. Madrid: Sociedad Española de Estudios Medievales, 2009: 121-143. 
in the $30^{\prime}$ s of $13^{\text {th }}$ century. Although they placed in different towns of the coast, the clearest evidence comes from the city of Valencia. According to the Llibre del Repartiment, seamen received houses between the Gates of Xerea and of Bebalcarrac, close to the river of Guadalaviar. ${ }^{4}$ However, in an inaccurate moment of the $13^{\text {th }}$ century, fishermen and sailors concentrated in other part of the city, between the present street of les Barques - the Boats, the name is quite expressive-and the plaça de l'Ajuntament. They were closed to the first Christian shipyards -located in the present plaça d'Alfons el Magnànim - but also closed to the marshlands and channels of Russafa that connected easily with the lake of l'Albufera. ${ }^{5}$ So, they could combine fishing in the sea and in the lake. As in the capital, in the rest of the kingdom, they lived inside the walls of the towns, which were located at a certain distance from the coast. The expulsion of the Muslim population from the most part of the coastal area in 1248 made fishing an essentially Christian activity. Nevertheless, some Muslim families were forced to reside in the island of el Palmar, in the lake of l'Albufera. ${ }^{6}$ Also in the coast of Midlands, where Muslims were not expulsed, it can be detected the presence of Muslim fishermen although they were not skippers, but simply sailors.

In order to consolidate colonization and attract the presence of fishermen into this world but also given the scarce profits that fishing could generate in a coast like the Valencian one, most of the feudal lords, including the king, conceded the free exploitation of these waters to their vassals. The same can be said about marshlands and pools. Although vassals did not have to pay seignorial rents, they had to satisfy the ecclesiastical, like the tithe and the primicia, that in many cases belonged to the feudal lords. For instance, in the city of Valencia, fishermen could fish freely although they have to pay the tithe to the king, a fifth in the case of catches from the lake of l'Albufera and a tenth for the fish from the sea. Besides these rents, for fish had to be paid local taxes, particularly the cises (tolls), an indirect tax levied on products of consumption, although they were lower than other foods like meat or wheat.

\section{Between the land and the sea: a socioeconomic analysis of fishermen}

On 26 November 1495, Antoni Masén, agricola et pixcator, and his wife Joana inhabitant of the coastal town of la Vila Joïosa, in the coastal Midlands, admitted to owing the Muslim Sale Polopi, a rich man from the Muslim quarter of Cocentaina, 276 shillings (sous) 8 pences (diners). for which they had bought 20 bucks (male

4. Llibre del repartiment, ed. Antoni Ferrando Francès. Valencia: Ajuntament de València, 1978: 64.

5. Torró Abad, Josep; Guinot Rodríguez, Enric. “De la Madîna a la ciutat: les pobles del sud i la urbanització dels extramurs de València (1270-1370)", Saitabi, 51-52 (2001-2002): 51-103, particularly 70.

6. Salcedo Abizanda, Salvador. Estudio histórico-jurídico de la Albufera y de su aprovechamiento. Castelló de la Plana: Sociedad Castellonense de Cultura, 1967: 17. 
goats). ${ }^{7}$ This deal reflects with quite precision one of the central features of fishing in Valencia during the middle ages and the early Modern era. For the notary that registered the transaction, Guillem Peris, Masén developed both activities, fishing and farming, in his daily life and, because of this, he did not doubt to describe Masen both as a peasant and as a fisherman.

Like Masén, most of fishermen in medieval Valencia had one foot in land and the other in sea since the right moment of the creation and consolidation of the kingdom. For them, fishing and farming coexisted as complementary activities. The degree of complementarity between land and sea depended on each particular case. So, the life-cycle of the family and the level of fishing specialisation conditionate the size of the holding, but we should not think beforehand that fisher's holding were smaller than the strictly peasant's one. ${ }^{8}$ Besides farming, the complementarity may involve other economic activities, apart from the work done by women and children. In this case, Antoni Masén bought some heads of livestock to that seems to be for reselling them or inseminating a flock but, in any case, for a later transaction. In other cases, they were artisans and other professionals that fished as a sideline economic activity. ${ }^{9}$ However, in most occasions the alternative source of incomes was exclusively the possession of some plots of land.

The search of external incomes, particularly in farming, suggests the insufficiency of fishing for guarantying the viability of the household. Nonetheless, the diversification of sources of income cannot be attributed only to the meagre benefits of fishing activities. On the one hand, we cannot forget the prominence of land in Feudal society. From the king to the poorest man, all we bound to land as the main source of power, richness and food. Possessing some plots of land, fishermen sought to guarantee the access to the central characters of the Medieval food system: bread and wine. ${ }^{10}$ When we can identify the crops cultivated in fishermen's lands, they were always cereals and vineyard. ${ }^{11}$ On contrary, they did not farm crops related to the industrial or speculative agriculture such as sugarcane or flax.

On the other hand, fishing depended, much more than any other economic activity, on the weather and the conditions of the sea. Beyond the need of secure the supply of cereals and the conditions of the sea, we cannot forget that, more than any other food, fish had an inelastic demand. Its consumption increased significantly during the days of abstinence. Those days of required abstinence by the Church were Lent, Ember days, Christmas Eve, the Assumption of Mary Eve, and St. Phillip, St.

\section{ACCV. Protocols, No. 23818.}

8. The fisher Pere Carreter, resident in Valencia, bought 19 fanecades (1,5 ha.) of cereal land from the peasant Martí Carreter for 500 shillings (sous). It is possible that they were relatives but no reference about it is mentioned. ACCV. Protocols, No. 21873, without folio (2 May 1467).

9. The surgeon from Peníscola Guillem Caiforàs accepted owing 96 shillings (sous) remaining of a larger quantity de preu de cordes d'espart ("for the price of straw ropes") that he bought Guillem Olzina, ropemaker from Valencia per obs de pexcar ("for fishing"). ARV. Batlia, No. 1448, f. 4lr.

10. Garcia Marsilla, Juan Vicente. La jerarquía de la mesa: los sistemas alimentarios en la Valencia bajomedieval. Valencia: Diputació de València, 1993: 76, 245.

11. See, for instance, the example mentioned in note 8 . 
James and St. John Eves, but also on Fridays in every week. Furthermore, preachers such as Vicent Ferrer and Francesc Eiximenis encourage people to carry out the abstinence during Advent and from the Ascension to Pentecost. ${ }^{12}$ It seems logical to think that these ups and downs of the demand had to have some effect in the fishing labour market. Therefore, during the days of rough sea or the reduction of the demand many fishermen work on farming.

Despite these factors that must be taken in consideration, it is undoubted that fishermen were one of the lesser social groups in medieval Valencia. Obviously, as any given collective, also among the fishermen we find a broad range of socioeconomic differences, from those who fished as labourers to those who owned the boat and the nets for fishing, although all of them appear referred as pescadors in the sources. In Castelló de la Plana, the Llibre de la peita - a register of the possession of buildings and lands of the inhabitants - of 1398 mentioned eight fishermen. Five of them had personal assets estimated under 600 shillings (sous) but, on the other extreme, Pere Borràs' possessions were valued at 7,750 shillings (sous). His personal assets included different houses, a piece of land (solar), and a holding of 4 ha. in different plots that included orchards, cereals land and vineyards. ${ }^{13}$ And this example is not unique. For instance, in 1381 the fisherman Berenguer Dalmau was one of the twenty-nine inhabitants in Gandia which personal assets were estimated in more than 4,000 shillings (sous)..$^{14}$

Despite these rare exceptions, the possibilities of enrichment with fishing were quite limited. Registries of personal assets show them on the lowest rank among the community, like in Castelló de la Plana. Regarding to notarial records, fishermen used to appear contracting a debt or acting like sellers. And these debts have to do with the main necessities like foodstuff more than with investments. ${ }^{15}$ When they acted as buyers it was, principally, for acquiring equipment for fishing such as boats and nets or for buying plots of land, as it has been aforementioned.

This limited economic capacity had its correlation in a low participation in the local administration. Fishermen were not engaged in any relevant political posts such as jurat (councilmen), batle (bailiffs) or justícia (mayor), having access only to the local council, like in Castelló de la Plana. ${ }^{16}$ There were, however, some scarce exceptions. Francesc Cabrera, inhabitant of the town of Cullera, admitted having fished in the river Xúquer in front of the ecclesiastical authorities that demanded him and the fishermen of Cullera for evading the payment of the tithe and the primicia. The lawsuit informs us that Cabrera served as one of the councilmen of Cullera during 1492. But what is more interesting is that Cabrera was not referred

12. Garcia Marsilla, Juan Vicente. La jerarquía...: 75-76.

13. Aparici Martí, Joaquim. "Hombres de mar...": 1109.

14. Colección de documentos para la historia de Gandia y su comarca, ed. Josep Camarena Mahiques. Gandia: Instituto Laboral, 1961: I/2, 41-56.

15. So, the fisher from Valencia, Pere Baldoví admitted owing 1,160 shillings (sous) to Joan Corberà, a ropemaker from Alcalà de Xivert, debitos de et pro finamento compoti inter no et vos, facti de pane, vino et aliis necessitatibus. ACCV, Protocols, No. 23012, without folio (1 March 1491).

16. Aparici Martí, Joaquim. “Hombres de mar...": 1096. 
in the lawsuit as a fisherman but as a farmer and, indeed, he stated fishing only sporadically. ${ }^{17}$

Besides risking their lives, fishermen had to deal with other dangers such as being attack and seized by Muslim pirates, Christian corsairs or maritime thieves, when not Valencian magnates like Joan Roís de Corella, son of the Count of Cocentaina. The young magnate with his galley hijacked two boats of fishers from Valencia that claimed to the Court of Batlia. ${ }^{18}$ Finally, one of the boats was taken to Alacant while the other was released paying 3,000 shillings (sous). ${ }^{19}$ Selling the goods seized or obtaining a ransom for the rigging and the fishermen were the central aim of these actions. For getting back their belongings, fishermen appealed to the different courts, although the tribunal of the Batlia conserves more evidence. ${ }^{20}$ Besides these problems, in land, fishers had to deal with the robberies in their barraques - fisher cottages for keeping the boats and rigging - , which were not strange. ${ }^{21}$

So, the limited profits, the insecure of the sea and having to risk their own lives make fishing fairly unattractive for medieval people. Despite the lack of absolute numbers, different sources suggest that there were not enough fishermen in the kingdom for satisfying the demand of fish. Obviously, this is a trend general that cannot be said for the whole territory and during all the medieval period. The city of Valencia, for instance, probably was an exception of this. On contrary, some coastal towns had difficulties for providing fresh fish for their inhabitants. Because of that, local authorities had to promote the arrival of foreign fishermen with policies such as the exemption of municipal taxes or conceding a house for him and his family. So, for instance, the council of Vila-real concede the fisher Pasqual Mas a subsidy with the condition that he became vehi de la dita vila e tenint aquella provehida del peix que pescara. $^{22}$

These requests by local councils and the pursuit of better work conditions, besides personal matters, promoted the movement of fishermen long the kingdom. It is true that mobility was a common feature of the society in all the Medieval West, but in the case of fishermen, unless in the kingdom of Valencia, they moved from one place to another. In the area of la Plana, in the coastal Northlands, at the end of $14^{\text {th }}$ century the $15 \%$ of fishermen were not natives

\section{ACV. No. 3632, without folio (10 April 1492).}

18. The possession of galley and ship was not strange among Valencian magnates. Also the noble Hug de Cardona had a galley. Hug de Cardona. Col-lecció diplomàtica (1407-1482), ed. Ferran Garcia-Oliver, Frederic Aparisi Romero, Noelia Rangel López, Vicent Royo Pérez. Valencia: Publicacions de la Universitat de València, 2011: 740-744.

19. ARV. Batlia, No. 1151, f. 644r (5 January 1453).

20. So, for instance, Bartomeu Tasio and Guillem Stanyol, two fishers from Valencia, claimed to the Batlia's Court being attacked by the galley of Llop de Mallorques, that seized certs homens e exarcia ("some men and nets"). Finally, they could release their workmates and got back their nets. ARV. Batlia, No. 1148, f. 442r (6 May 1438).

21. ARV. Batlia, No. 1147, f. 277r (16 July 1431). See examples in Vila-real in Aparici Martí, Joaquim. "Hombres de mar...": 1090-1091.

22. "inhabitant of the town and providing it with the fish that he fishes", cited by Aparici Martí, Joaquim. "Hombres de mar...": 1095. 
of the towns where they have been documented. ${ }^{23}$ Such mobility was mainly of regional range but also of larger distances. In Castelló de la Plana through the $15^{\text {th }}$ century was possible to find fishermen from Narbona (France) and from Vizcaya (Castile). ${ }^{24}$

In the capital of the kingdom the origin of fishermen was more diverse, attracting people from the own region - from Vinaròs, Castello, Oliva, among other towns-, but also from abroad - Catalonia, Portugal, France and Castile. ${ }^{25}$ Here, official requests were unnecessary since the demand of the local market and the possibilities of fishing both in sea and in the lake of l'Albufera attracted fishermen. Thanks to the Llibres d'Aveinament - records of settling-, we know that, between 1371 and 1400, 82 seamen settled in the city of Valencia, representing a $6 \%$ of the total. For the next period registered, 1421-1449, 42 seamen arrived at Valencia becoming a $6{ }^{\prime} 5 \%$ of all immigrants. ${ }^{26}$ Obviously, not all fishers that settled in the city were registered in those records but only those that aspired to obtain the benefits of becoming inhabitant of Valencia. For instance, neither Jaume Ferrer nor Gonçal de Trujillo appeared in the Llibres d'Aveinament but both fishermen, from Oliva and Eivissa respectively, settled in Valencia and developed their profession. ${ }^{27}$

Given that it was rough making a living as fisherman, wives had a crucial role in the domestic economy. Women used to collaborate with their husbands repairing the nets but, overall, selling the fish. Local ordinances did not mention them specifically, but they were described by literature. The physician Jaume Roig in his misogynist work l'Espill depicted those women as crooks and rip-off dealer since they used to sell bait as fresh fish and captures from the Albufera and the Xúquer as from the sea. ${ }^{28}$ Beyond their collaboration on activities related to fishing, they contributed to the domestic economy with external jobs. Magdalena, wife of the fisher Domingo Andrés of Valencia, received 50 shillings (sous). from a widow name Masiana for taking care of her for two years, although we do not know exactly which her duties were. ${ }^{29}$ Also in Valencia, Francesca

23. Aparici Martí, Joaquim. “Hombres de mar...": 1095.

24. Aparici Martí, Joaquim. “Hombres de mar...": 1095.

25. Piles Ros, Leopoldo. La repoblación de Valencia a través de los "libres de avehinaments" (1400-1449). Valencia: Ayuntamiento de Valencia, 1978.

26. Cruselles Gómez, Enrique. “Dinámica demográfica: red urbana e inmigración ciudadana en al Valencia bajomedieval". Saitabi: revista de la Facultat de Geografia i Història, 53 (2003): 35-56, particularly 55.

27. Respectively, ACCV. Protocols, 20543, without folio (25 October 1490); No. 17457, without folio (26 November 1509).

28. Les pescadores, grans robadores/ són d'entradós, de caladós e bruginés, al vendre més/ pex de fer esc, venen per fresc/lo d'Albufera, riu de Culleral per pex de mar ("Fishermen's wives, great thieves/ are of brogina nets and fishing grouds. They sell bait like fresh fish/ fish from the Albufera or the river of Cullera/like sea fish"). Roig, Jaume. L'espill o Llibre de les dones, ed. Marina Gustà i Martorell. Barcelona: Edicions 62, 1978 : 117. 29. "Despite that, it seems a wage lower than other contracts registered". ACCV. Protocols, No. 23029. without folio (1 July 1501). 
received 360 shillings (sous). from the knight Francesc Corts' widow, Joana, for breastfeeding her son, Andreu Miquel for one year. ${ }^{30}$

Before getting married, some of these women had started working as an apprentice maid when they were younger to gather her dowry, or unless some part of it, like Caterina. She was in domestic service on the Francesc Vilar's house in Valencia for which she received 280 sous pro suplemento sue dotis. ${ }^{31}$ This type of contracts suggests that fishermen found their wives among families with limited resources that had to send their daughters to work in others' house to assemble their dowry. ${ }^{32}$ Consequently, the volume of the dowries should be modest. Indeed, although there were not absolute numbers, the contracts of marriage involved by fishermen are rare in notarial records.

Due to that, it cannot should be ruled out that most of these marriages were agreed orally between the families of the candidates and, hence, the notarial contract was not required. Following with this argument, it seems logical that the new family was regulated by a germania regime, although it was quite marginal in most part of the Valencian kingdom at the end of the middle ages, even among lower sections of the population. ${ }^{33}$ Indeed, I have evidence that the regime of dowry also existed among fishers. Miquel Lloret, a fisherman from Valencia, married her daughter Úrsula with a young fisher also from the city, Nicolau Aliaga, better known as Suret, providing her with a dowry of 200 shillings (sous). ${ }^{34}$ However, the dowry could reach the 600 shillings (sous) with which the fisherman from Valencia Vicent Mateu gave to his daughter. ${ }^{35}$ They are modest sum, comparable with lower ranks of peasantry. ${ }^{36}$ More evidence would let us to determine how much these cases represent the use of the dowry regime among fisher families in front of germania system, and the value of the dowries of their daughters. ${ }^{37}$

30. debitas de uno anno rationes lactationis per me facte dicto Andree Michaelis. ARV. Protocols, No. 1902, without folio (9 September 1433).

31. ACCV. Protocols, No. 27362, without folio (31 May 1446).

32. After getting married, Joana appointed her husband, the fisher from Vila Joiosa, Genis Mingot, as her legal representative for collecting the payment of her works. ACCV. Protocols, No. 23817, without folio (6 October 1494).

33. Viciano Navarro, Pau. Els peus que calciguen la terra. Els llauradors del País Valencià a la fi de l'edat mitjana. Valencia: Publicacions de la Universitat de València, 2012. In the kingdom of Valencia coexisted two regimes to regulate the economic relation between the married couple. One was the germania in which the couple put together their assets. When some of them died all the assets had to be split in two equal parts and then give one to the living member of the couple. The other system was the dowry or separation of property regime. This system gave more economic protection to the wife since the husband could not manage the dowry in any circumstance. Indeed, if the wife died, her dowry could return to her family or, in case of having children, to them.

34. ACCV. Protocols, No. 11919, without folio (6 July 1433).

35. He gave 300 shillings (sous) in cash and 300 in clothes. ACCV. Protocols, No. 27362, without folio (14 August 1446).

36. Viciano Navarro, Pau. Els peus...

37. Another example is the transaction of a cottage between Eulalia la Serrana, Francesc de Magalló's widow, and Isabel, Joan Lleopart's wife. Given that the cottage had previously belonged to Isabel —ementi de propris bonis vestris, the document says-, it could be concluded that the cottage was part of the assets 
Regarding the social background of the candidate, it seems that fishermen used to marry their daughters with members of the group or with peasants. I have not found evidence of marriages between a craftsman and fisher's daughter. So, for instance, the fisher form Gandia Antoni Despent married his three daughters - Guillamona, Maria and Antònia - with three fishermen of the town, Joan Garcia — that we know he had his own bolig-, Antoni Bolea and Antoni Pelegrí, although the marital regime is not mentioned. ${ }^{38}$ Also the aforementioned Vicent Mateu married his daughter with another fisherman, Francesc Vallés.

If youth was rough, dealing with old age was not easier, particularly for fishermen's widows. For that women that were widowed too old for contracting a new marriage, to be in a domestic service provided them with a roof and a company until their last days. On 18 June 1416 the peasant Pere Julià from Benetússer, a village close to Valencia and near to l'Albufera, admitted owing to the incredible sum of 3,360 shillings (sous) to Francesca, widow of the fisherman Martí Navarro, also from Benetússer, ${ }^{39}$ 1,920 shillings (sous) were owed rationes servitutis duodecim annorum per vos michi facte ad forum sive rationem octo libris pro quolibet anno. The rest, this is 1,440 shillings (sous), respond to the leasing of Francesca's properties, which could include lands basically, since it seems habitual that fishermen's widows sold the boats and tackles of their husbands if they had. But just after this indebtment, Francesca signed a contract of afermament by which she became his housemaid for the next ten years perceiving 160 shillings (sous) per year. ${ }^{40}$ It is not strange that these relations could generated emotional ties between the parts. Half year later, Pere Julià named Francesca one of the executors of his will apart from Bernat Mateu, a fisherman as Francesca's husband..$^{41}$

Precisely testaments, as inventories post-mortem and public auctions, are quite rare among fishermen, in spite of the ecclesiastical obligation for dictation the last wills. Those we find respond to not only this demand of the Church but also the need of organising and distributing their goods. So, the wills of fishermen found tend to be medium or upper ranks of the group like Joan Sisteró, fisher from Valencia, that willed on 3 January $1490 .{ }^{42}$ The place for being buried, a tomb in the monastery of Sant Francesc in Valencia where lied the remains of his grandmother and three brothers, denotes the well-off position. He spent for carrying out his wills

integrated in Isabel's dowry. Indeed, Eulalia was selling it to her, and not to her husband, alive yet. Isabel and Joan, therefore, had to be married in dowry regime. ACCV. Protocols, No. 373, without folio (21 February 1486).

38. AHN. Nobleza. Osuna, leg. 1173, No. 2.

39. The quantity is comparable with the rents of some small modest in the Horta of Valencia such as Espioca and Rascanya, that generated each of them 3,000 shillings (sous). of rents to their respective lords. Viciano Navarro, Pau. Senyors, camperols i mercaders. El món rural valencià al segle XV. Catarroja: Afers, 2007: 196.

40. She became in mancipiam vestram hinc ad decem anno primoventuros et continue segquentes et quod vos, dictus Petrus Julià, teneamini me providere de petu et ciba, calciatu et vestitu tam in sanitate quam in malaltia. ARV. Protocols, No. 1885, f. 121 v. (18 June 1416).

41. ARV. Protocols, No. 1886, f. 18r (29 January 1417).

42. AHN. Nobleza. Osuna, leg. 1307, doc. 9. 
200 shillings (sous), what is a considerable sum amount medium and well-to-do sectors of Valencian peasantry. ${ }^{43}$

In the previous lines I have given different evidence of the rough living conditions that featured fishermen. The foundation of the hospital of en Bou in Valencia shows that this poverty did not go unnoticed for the contemporaries. In 1396 the merchant Pere Bou found a hospital close to the Gate of Russafa and near to the neighbourhood of the fishermen. The singularity of the hospital of en Bou among the others existing in the city is this one was the unique centre destined to a specific professional group. ${ }^{44}$ It was founded exclusively for fishermen, even their wives and children were excluded. Despite the lack of sources of the own institution, it seems that it was not a big centre, but its services were crucial for the fishermen. Because of that, the local authorities decided not to include it in the concentration of the different hospitals existing in the city that resulted in the creation of the General Hospital in 1512. Indeed, the hospital of en Bou existed until the $19^{\text {th }}$ century although in the last centuries it was opened to all kind of people.

Despite the Pere Bou's foundation, it must be said that fishermen of the city of Valencia had their own collective guild and their brotherhood known as the Comú de pescadors. ${ }^{45}$ It was one of the oldest guilds of the city given that it seems to be created as early as in $1238 .{ }^{46}$ Unless during the decades after conquest, fishermen from Valencia worked both in the sea waters and in the Albufera lake. In summertime they fished in the sea due to the better maritime conditions and during the winter in the lake. However, in the second half of the $14^{\text {th }}$ century the maritime fishers split up from the Comú and created their own guild. Due to the protests of the Comú, the Crown forced them to return to the previous situation. Ulterior attempts of splitting occurred, but the Crown always resolved against the petitions of the maritime fishers. These conflicts suggest an increasing level of specialization and differentiation between the two collectives.

The guild was managed by four good men chosen by the royal bailiff and the lessee of Quint reial — the tithe, the fifth part of the captures. ${ }^{47}$ These men regulate the fishing areas of the lake and resolved the disputes related to the work among fishers both in the lake and in the sea. At the end of the $14^{\text {th }}$ century fishermen from larger villages surrounding the lake were forced to be included in the Comú. This also generated disputes, so the managers had to ask the royal authorities to force those village fishers to pay the fees. The guild created the brotherhood in 1308

43. Aparisi Romero, Frederic. Del camp a la ciutat. Les elits rurals valencianes a la baixa edad mitjana. Valencia: Universitat de València (PhD Dissertation), 2016: 340-348.

44. Rodrigo Pertegás, José. “Hospitales de Valencia en el siglo XV: su administración, régimen interior y condiciones higiénicas". Boletín de la Real Academia de la Historia, 90 (1927): 561-566.

45. Despite the capital became a model for the rest of the kingdom in many aspects, there is no references to the creation of similar guilds in other towns, although it should not be ruled out their existence either. 46. González Arce, José Damián. "Las cofradías del mar en la Corona de Aragón (siglos XIII-XV)", Espacio, Tiempo y Forma. Serie III. Historia Medieval, 21 (2008): 285-310, particularly 291-294.

47. Vendrell de Millàs, Francesc. “Ordinacions en favor dels pescadors de l'Albufera i de la mar de la ciutat de València", Medievalia, 10 (1992): 479-493. 
dedicated to St. William headed in the monastery of la Trinitat, although in 1392 they changed the dedication in favour of Saint Andrews.

Regarding Muslim fishers, evidence is scarce. Before 1248, when the Muslim population was expulsed from most part of the coastal areas of Valencia, it could be possible to identify Muslim fishers, proof of the previous stage before the Christian conquest. However, since the expulsion and given the concerns of Christian authorities on an evasion of Muslim vassals, fishing was a rare activity among Muslim population. Despite that, particularly in the coastal Midlands but not only, some Muslim fishers have been registered. Still in 1288 in Valencia, a fisherman called Alfaquim had his workshop adjacent to the church of St. Catherine, although he should be one of the last Muslim fishers living in the city. ${ }^{48}$ Habitually, the owner of the boat used to be Christian while the labourers could be Muslim fishers. The evidence comes from contacts for working as labourers in bolig nets, as we will see. However, there were exceptions. On 12 February 1460, the fisher Miquel Irles from Valencia, demanded 150 shillings (sous) to Suleimen Funi remaining of greater quantity for buying a boat and a bolig. ${ }^{49}$

\section{Putting out to sea: techniques of fishing and captures}

In medieval Mediterranean predominated seaside over deep-sea fishing and the kingdom of Valencia was not an exception. Fishing was developed near to the coast, so vessels as big as whaleboats were not required. On contrary, we find a range of different type of boats, that were used according to the type of fishing developed, although most of them combined sails and oar as a means of propulsion. Then number of banks and oars determined the size of the boat so there was not a unique type. However, except from some cases, written sources tend to be vague on this matter and they talk about fishing boat in general.

In relation to the means of production for fishing, there were three basics elements, the boat, the nets and hooks, and the cottages for putting the tackle away. How much did they cost? There is no a definitive answer for it since the price varied according to the size and the state of preservation, particularly in the case of boats. On contrary, nets needed to be replaced more frequently so the market of second hand was less common. ${ }^{50}$ So, a boat could cost from 140-200 shillings (sous), the smaller ones, to 1,600 shillings (sous) the larger, although in this case it incorporated

48. Llibre de la Cort del Justícia de València (1287-1288, 1298), ed. Aureli Silvestre Romero. Valencia: Publicacions de la Universitat de València, 2008: 530.

49. ARV. Batlia, No. 1153, f. 35r.

50. Despite that, there are some examples of it. On 9 February 1442, Lluís Montoro, fisher from Valencia, claimed in the court of Batlia against Joan de Lorca from Benidorm since he did not give back a Montoro's net. This fishing net la qual seria stada e fou acomanada al dit en Johan de Lorqua per n'Alfonso Martí, pescador de la dita Ciutat, tro a huy ("had been entrusted until today to the aforementioned Johan de Lorqua by Alfonso Martí, fisherman from the said city"). ARV. Batlia, No. 1149, f. 160r. 
all the rigging. ${ }^{51}$ A medium size boat could be valued between 500 and 800 shillings (sous), depending on what was included in the transaction. Benet Comte, a fisher from Valencia, sold Guillem Guardiola and Ramon Serra, fishers from Gandia, the barcham meam de palangre de quatre parells de rems ${ }^{52}$ for 550 shillings (sous) while the Miquel Gomis's widow sold the fisher Esteve Cassio from Valencia quandam barcham de quatre parrels cum omnibus suis exarciis et cum sex pesis de bonitoleres for 760 shillings (sous)..$^{53}$ In both cases it was a second-hand boat but if it was new, obviously the price was higher. Pere Cortés, fisher from Vila Joiosa paid only for the boat 880 shillings (sous)..$^{54}$

So, the minimum investment for fishing, around 150 shillings (sous) for a boat, was comparable to the purchase of a medium-high quality draught horse or to 75 working days as labourer, considering 2 shillings (sous)/day during the $15^{\text {th }}$ century. ${ }^{55}$ In other words, while Valencian peasants could have access to a ploughing horse without excessive economic difficulties, fishermen had to work two months and a half for acquiring a small boat. It could be possible, therefore, that the possession of a boat became an element of stratification among fishermen, although more research needs to be done on this issue. Furthermore, the type of the draught animal did not sort peasants as clearly as the kind of vessel and nets did among fishermen. Those who can achieve tuna and bonito nets obtained more profits than those who fished smaller species.

Fishermen owning more than one boat are quite strange. ${ }^{56}$ On contrary, the cases of fishers having to lease the boat for fishing are more common. Particularly rural elites and well-to-do peasants invested acquiring boats and then leasing them to local fishers, as Lluís Blasco from Borriana. Having a holding of more than 10 ha, a wine press, a distaff for spinning wool, draught animals and sheep, and servants it is quite obvious that he was not a fisherman but a rural entrepreneur. Among these and other goods, Blasco had:

una barqua y hun exabech ab ses veles e rems, tres àncores e sos caps, deu peces de bonitoleres velles y molt sòtils ab sis cabaços de [...] bordes y cinch menuts, una caldera de dos cànters

51. Bernat Ribes from Oliva sold Bartomeu Alcocer a boat for 140 shillings (sous). ACCV. Protocols, No. 6464, without folio (11 August 1430). Ramon Serra from Gandia sold una barca de pexcar ab certa exarcia ("a fishing boat and a net") for 200 shillings (sous). AHN. Nobleza. Osuna, leg. 1122, No. 8-1, without folio (30 August 1478).

52. "my boat of longline hooks with four oars pair". AHN. Nobleza. Osuna, leg. 1272, No. 6, without folio (7 January 1466).

53. ACCV. Protocols, No. 22488, without folio (15 October 1483).

54. ARV. Batlia, No. 1153, f. 289v (21 April 1462).

55. Viciano Navarro, Pau. "El mercat d'animals de treball en una vila valenciana del segle XV", Recerques: Història, economia i cultura, 52-53 (2006): 141-159, particularly 152.

56. Andreu Pallerés, from Castelló, had in 1371 two boats valued in 300 shillings (sous). Aparici Martí, Joaquim. "Hombres de mar...": 1092. 
y una paella. Ítem, una barca al guerau de Burriana y altra al tragol de Almaçora e deu o dotze senyals de carabaces. ${ }^{57}$

Also fishers leased their boats to other colleagues. Miquel Irles from Valencia claimed payment of 21 sous restants de major quantitat per loguer de una barqua to Jaume Amat from Alacant. Besides he requested 9 sous per preu de portar la dita barqua del loch de Benidorm a la platja del guerau de la ciutat de València. ${ }^{58}$

Besides the boat, fishermen had to buy nets and hooks for fishing and, every so often, changed them. The type of seine used to refer the technique of fishing, having them all in common that they were collective systems. ${ }^{59}$ These nets were known as bolig —or bolitx - xàvega (both considered trawling nets), palangre (paternoster line) and tonaira (tuna net or almadraba) and bonitolera (bonito - Sarda sarda- net). ${ }^{60}$ Both the bolig and the xàvega, a bigger bolig, were cast in sea and then stretched from the shore or closing the net with two boats. They fished different species indistinctly. On contrary, palangre, tonaira and bonitolera were for fishing larger fish, particularly tuna and bonito, although also dolphin, eels, swordfishes and similar big species could fall into ${ }^{61}$. Furthermore, while bolig and xàvega were mobile nets, the palangre, tonaira and bonitolera were drift, casted in sea and fixed there for the night. ${ }^{62}$

All these seines required the work of different fishermen, creating companies for the exploitation. The owner of the boat and nets contracted different men -both Christian and Muslim fishers in the area of the coastal Midlands- that worked with him during all the Winter and Spring, until the harvest time. For those labourers, therefore, fishing was also a temporal job. Indeed, these work relations used to be unequal since frequently -and because of it we have the evidence of these companies - the owner advanced the wages. So, for instance, Abdal·la Albasar, a

57. "a boat and a xebec with its sails and oars, three anchors with their heads - this was the iron part of the anchor - ten old nets for bonito fish with six baskets [...] and five small, a copper and a paella —for cooking in sea. Ítem, a boat in the beach of Borriana and another in the wetlands of Almasora, and ten or twelve signals of marrow". ACCV. Protocols, No. 23024, without folio (2 November 1502). See also Aparisi Romero, Frederic. Del camp...: 114-115.

58. "21 shillings remaining of a larger sum for leasing a boat»", "9 shillings, price of carrying the aforementioned boat from the place of Benidorm to the beach of the city of Valencia". ARV. Batlia, No. 1152, f. 1451r (11 April 1458). Irles, besides, sold a boat and bolig net to a Muslim fisher. See footnote 49. 59. Obviously, there were other systems for fishing individually besides rod, such as the creel and the casting net. The possession of these seine did not imply necessarily an active dedication to fish. So, for instance, among the diverse stuff inventoried in Domingo Garcia's house, a peasant from the small town of Oliva, a casting net was registered. ACCV. Protocols, No. 28753, without folio (3 September 1428).

60. Aparisi Romero, Frederic. "La pesca marítima en temps d'Alfons el Vell en el ducat de Gandia i el comtat de Dénia", Comercio, redistribución y fondeaderos. La navegación a vela en el Mediterráneo: V Jornadas de Arqueología Subacuática, José Pérez Ballester, Guillermo Pascual Berlanga, eds. Valencia: Universitat de València, 2008: 373-381, particularly 378-379.

61. This image of the nets and fishes that felt into them were frequently used by medieval clergymen in their sermons. Aparisi Romero, Frederic. “La pesca durant l'edat mitjana a través de les fonts literàries catalanes", Nuevos estudios multidisciplinares sobre historia y cultura medieval. Fuentes, metodología y problemas, Jerónimo Méndez Cabrera, Diego Antonio Reinaldos Miñarro, eds. Murcia: Editum-Universidad de Murcia, 2012: 13-24, particularly 19.

62. Ayza Roca, Alfred. “La pesca...": 167-169. 
Muslim from Albaida, an inner town of the Midlands, started to work in the bolig of Bartomeu Vallobar, fisherman from Gandia, on 18 October 1388. The Muslim admitted owing him 25 shillings (sous) and compromised to fish with him from October to the festival of Resurrection, when he would return the debt. ${ }^{63}$

Tuna seines or almadraba probably used the same system of companies. However, fishing with this seine generated some disputes at the beginning of $15^{\text {th }}$ century, unless in the County of Denia. In January $15^{\text {th }}$ of 1403 the count of Dénia, Alfons d'Aragó the Elder, wrote the council of the town saying that tuna seines had arrived from Catalonia. He depicted how these nets were not selective in the species arguing "they burn the seas". So, attending the councilmen's petitions, he forbade this kind of seine in his domains to both local and foreign fishermen. ${ }^{64}$ However, three months later, the count went back on his words because of the petition of the councilmen of Valencia. It seems that there was a scarcity of fresh fish in the capital and the count authorised fishing ab tonayres $e$ altres qualsevol arts en les mars dels dits nostres vila e lochs per tota la present Quaresma tan solament. ${ }^{65}$ Finished this period of higher demand the tune seine was forbidden again although it seems that his regulation was not respected so he had to insist on with more ordinances. ${ }^{66}$

While councilmen of Dénia agreed with his decision, their colleagues from Xàbia disagree. In March of 1405 they asked the count poder pescar alcún temps ab les dites tonayres en les mars del dit loch de Exàbea, to what the lord accepted les tonayres en les dites mars de Xàbea per tres meses solament, çò és, març present, abril e maig primervinents, $e$ no pus. ${ }^{67}$ All these incidents show the mobility of fishermen and their seines through

63. AHN. Nobleza. Osuna, leg. 1323-1324, without folio (18 October 1388).

64. les tonayres són gitades de Catalunya per ço com cremen les mars, que peix que no.y mor de exàvegues, boligs, batudes e palangres, que és lo bo de la cosa pública, e aquelles tonayres són estades portades en aquestes mars, on fan semblant dampnatge (...) revocan lo dit senyor qualsevol licències per ell ça entràs atorgades a qualsevol persones, axí stranyes com provades, sobre lo pesca ab les dites tonayres, si algunes apparrán ("the tuna nets are brought from Catalonia given that they burnt the seas because the fish that does not die due to the bolig and palangre nets, what is good for the res publica, and those tuna nets have been brought in these seas, where they cause the same damage (...) revoking, the said lord, any given licences by him previously given to any foreigner or local people to fish with tuna nets, if they will appear"). Colección de documentos...: 72 . Also ARV. Mestre Racional, No. 9568, f. 42v.

65. "any given person with tune nets or any given seines in our seas only during Lent". Colección de documentos...: 74 .

66. (...) alguns, temeràriament venints contra los dits nostres manaments e ordenacions han pescat e pesquen en les dites mars [de Dénia, Xàbia, Calp Altea i Benidorm] e altres dels lochs marítims nostres ab les dites tonayres e exàrcies de aquelles, així que ordenà que d'ací avant en les mars de les nostres viles e lochs de Gandia, Dénia, Exàbea, Calp, de Altea e de Benidorm e de altres qualsevol lochs marítims nostres, no.s pesque o sia osat pescar per alguns privats o estranys, qualsevulla sien o seran, ab les dites tonayres ("some people, rashly coming against our dispositions and ordinances have fished and fish in the said seas [de Dénia, Xàbia, Calp Altea and Benidorm] and other maritime places of us with the aforementioned tuna nets, so I order that from now, in the said seas of our towns and villages of Gandia, Dénia, Xàbia, Calp, of Altea and of Benidorm and of any given of ours maritime villages, no one, both local and foreigner, is allowed to fish with the mentioned tuna nets"). Colección de documentos...: 77.

67. “[people from Xàbia asked] for permission to fish some time with the tuna nets in the seas of the village of Xàbia [...] [the count allowed] the tuna seines in the mentioned seas of Xàbia for three months 
the coast of Catalonia and Valencia following the routes of the shoals. The interest of local authorities on this seine fluctuated depending how it could deprive of fish supplies their towns. On contrary, the councilmen of the capital of the kingdom was highly interested since they provided with fish in large quantities and with diverse species, bigger for the well-to-do ranks of the local population and smaller for the lower.

But how much did a seine cost? It is difficult to offer a definitive sum since it depended on the size of the net and the state of preservation, although also the type of it should influence in the final price. A second-hand bolig net, the most common seine registered, cost between 120 and 185 shillings (sous). ${ }^{68}$ Seine for fishing tuna or bonito should be more expensive, but it is difficult to give a number. The aforementioned Lluís Blasco from Borriana sold to Bartomeu Silvestre, a fisherman from Massanassa, next to the Albufera lake, two new tonaira nets, two new bonito nets, three pairs of oars and other fishing goods for 600 shillings (sous) ${ }^{69}$ And besides the nets, hooks need to be also replaced, although they were the most economic part of the rigging, near to 1 pence/hook. ${ }^{70}$

Beyond the price, it is quite clear that the capital of the kingdom played an essential role as market place for supplying all these means of production, particularly nets. Fishermen from all the coastal villages went to Valencia for acquiring nets. From the registries of the court of Batlia it seems that there were some ropemakers highly specialized in making nets like Arnau Olzina, although that does not mean obviously that seine could only be found in the capital of the kingdom. ${ }^{71}$ So, for instance, only in 1431, 273 shillings (sous), 6 pences (diners) were owed to this ropemaker by different fishermen from Dénia, la Vila Joiosa and Calp. ${ }^{72}$ But Olzina worked with fishers from all the kingdom. In 1435 Joan Colom from Cullera owed him 218 shillings (sous) but in 1437 Miquel d'Eslada from Peníscola owed him 500 shillings (sous) remaining of a larger amount. ${ }^{73}$

only, this is, the current month of March, the forthcoming April and May and no more)." ARV. Mestre Racional, No. 9568, f. 214v.

68. ARV. Batlia, No. 1153, f. 296v. (10 May 1462); No. 1148, f. 476v (26 November 1438).

69. (...) dues peces de tonayres noves, dues peces de bonitoleres noves, tres parells de rems, una entena e hun ferro de la barqua, una caldera e una paella, tres o quatre sclops et aliis rebus ("two new tuna seines, two bonito seines, three pairs of oars, one lateen yard and an anchor, a copper and a pan, three or four hawsers et aliis rebus"). ACCV. Protocols, No. 23.022, without folio (22 June 1495).

70. Jaume Ribelles paid 155 sous per raó e preu de dos milleres de ams que de aquell hagué comprats per a ops de peixcar ("155 shillings for 2,000 hooks that he bought for fishing"). ARV. Batlia, No. 1147, f. 297v (20 September 1431).

71. One regulation of the City Council in 1347 mentioned Alacant as another market of nets. Llibre d'establiments $i$ ordenacions de la ciutat de València, eds. Antoni Furió Diego, Ferran Garcia-Oliver. Valencia: Publicacions de la Universitat de València, 2007: 469-470.

72. ARV. Batlia, No. 1147, f. 282r.

73. ARV. Batlia, No. 1148, f. 66r (25 June 1435), 330r (18 March 1437). 
In the city of Valencia, the maritime activities were enormously difficult given the absence of a decent port, beyond a wood jetty. ${ }^{74}$ Indeed, the port lacked a lighthouse during all the Middle Ages. ${ }^{75}$ Given these deficiencies, fishermen had to remove their boats each day from the sea and place them on the shore. The wellto-do fishers kept them in barraques — the fishing cottages explained previously. These cottages were laid out on the shore, one next to the other, as it is depicted in the aforementioned transaction between Eulalia la Serrana, Francesc de Magallós widow, and Isabel, Joan Lleopart's wife. ${ }^{76}$ As it is referred in the document, fishermen could spend some time living there or, unless sleep before putting out to sea. So, Eulalia sold to Isabel:

Quandam barraquam meam dedicatam ad tenendum exarcias et res et bona designata ad piscadum et ibidem standum et quiescendum, et bona vestra tenendum, et ibidem constatuendum et conservandum, sitam et positam in litore maris, in loco vocato lo Cabanyal, confrontatam ab una parte inter barraquam que est ab uno latere barraque Bartholomei Tasio, ${ }^{77}$ piscatoris Valentie, et ab alio latere cum barraqua Petri Gomiç, alias lo Chamorro, piscatoris dicte civitatis, et aparte cum plagia maris et aparte retro ab lo cenillar.

The cost of the cottage was 140 shillings (sous) of which in the right moment of the transaction Isabel paid 63 solidos solutos in tribus ducatis auri, coins suggests that Isabel and Joan Lleopart did not belong to the lower ranks of the peasantry. This fisher cottage existed in all the Valencian coast. So, for instance, Bernat Burc claimed Antoni Tarrasa 32 shillings (sous), 6 pences (diners) that remained to be paid of higher amount for a fisher cottage situated in la Punta de la Albufera. ${ }^{78}$

It seems that fishing in the Albufera was quite similar to open seas, particularly in what refers to the main technique used, the bolig. Although the Albufera was integrated by James I in the royal heritage, it was pawned by his successors and released once and again until 1431, since when there were no more alienations. It is important to note that fishing in the lake had to be practised com en temps de sarrains, ${ }^{79}$ although we have no more references about what they implied.

74. Cruselles Gómez, Enrique. “El puerto de Valencia en el mediterráneo medieval (ss. XIII-XV)”, Historia del puerto de Valencia, Jorge Hermosilla Pla, coord. Valencia: Publicacions de la Universitat de València, 2007: 63-125.

75. In 1509 the merchant of Valencia Pere Cellés was granted with a privilege by the king Ferran the Catholic edificandi sive construendi in plagia gradus maris Valentie quondam lanternam sive faro. However, quodquidem privilegium ad instantiam sindici et rationalis presentis civitatis Valentie per dictam magestatem regiam fuit revocatum. ACCV. Protocols, No. 15457, without folio (21 May 1509). The resolution of the conflict implied that the lighthouse was dismantled but the Council had to pay the merchant 4200 s. for compensation. Pons Pons, Anaclet; Serna Alonso, Justo; Díaz Borrás, Andrés. “El primer intento integral de dotación portuaria en Valencia durante la era de los descubrimientos. Razones de un fracaso (14801520)". Anales de la Universidad de Alicante: Historia Medieval, 8 (1990): 169-186.

76. See footnote 37.

77. Probably the same person aforementioned in footnote 20.

78. ARV. Batlia, No. 1148, f. 382r (29 August 1437).

79. “like in the Muslim period". González Arce, Jose Damián. “Las cofradías del mar...": 292. 
Concerning inland fishing, except for the major rivers such as the Guadalaviar and the Xúquer, the irregular water level most of them made fishing a sporadic activity, limited to those points were the flow stagnated due to the orography or those moments of the year that rained most. Undeniable there were who fished occasionally although their activity, in general terms, has not generated evidence, and, in any case, it had to do with self-supply or with a very limited economic impact on local economy. Professional fishermen, on the contrary, were quite rare. In his 30 years of work in Cocentaina, where the river of Alcoi and other streams go through the town or the surrounding area, the notary Guillem Peris only registered one fisherman - Joan López- among its inhabitants. All the times López appeared in Peris' records, it was as a witness of other transactions. Beyond that, he was never involved in any act registered by Peris or any other notary of the town. As in the coastal area also in inlands fishing was mostly temporal work. In Alcoi, on $11^{\text {th }}$ October 1454, the court of justice condemned the peasant Guillem Vilaplana to pay 10 shillings (sous) to Joan Miralles per rahó de una barqua que de ell comprà. ${ }^{80}$ Although the boat could be used for crossing the river, this did not exclude being used for fishing.

More frequent seems to be fishing in the mouths, where fishermen from the coastal town came. It is the case of towns such as Gandia and Cullera, where the river of Alcoi and the Xúquer flew into the Mediterranean Sea. In Gandia, the local council banned fishing in the river with any kind of net or trap arranged in the river, what means that this was a habitual practice. ${ }^{81}$ In Cullera, river fish had a major economic role due to the higher flow of the Xúquer. So, fishermen worked both in open waters and, in the days of rough sea, in the river. They took advantage of those species that migrated from upstream to the sea such as sturgeons, lampreys and, particularly, shads. ${ }^{82}$ In April of 1492 the ecclesiastical officers collecting the primicia wanted to clarify how much of this fish was caught in the sea and in the river. The questioning of Francesc Cabrera enlightens us about the fishing techniques. They fished with a type of net named tir, probably similar to a dragnet, also used in sea fishing. Cabrera explained that algunes vegades l'aygua del dit riu lança los tirs en la mar [...] en los quals prenen algunes çabogues però que [no] sàpia quantes n'i prenen ni quantes no [...], ni si's prenen dites çabogues en lo riu o en la mar. ${ }^{83}$

Since they depended on the place of fishing not the value of the catches, the collection of the tithe and primicia generated some problems with fishermen and their representants. So, as it has been mentioned, by April of 1492 the bishop's officers the inhabitants of Cullera since they combined the catches from the river

80. "due to a boat from him (Miralles) that he (Vilaplana) bought". AMAlc. No. 274, f. $321 \mathrm{r}$.

81. Llibre d'establiments de Gandia. Imatges i missatges e una vila medieval, ed. Ferran Garcia Garcia. Gandia: Ajuntament de Gandia, 1987: 108, 114-115.

82. Documents referred to Alosa fallax nilotica (both in Catalan and Spanish saboga). Roca Cabau, Guillem. "Provision and consumption of fish in a Catalan inland city during the fourteenth and fifteenth centuries: the case of Lleida". Imago Temporis. Medium Aevum, 15 (2021): 268-301.

83. "sometimes waters of the river take the nets into the sea [...] and those nets catch shad but he does not know how many they catch [...] and if they catch the shads in the river or in the sea". ACV. No. 3632, without folio (10 April 1492). 
and from the sea. Francesc Cabrera, one of the councilmen and the representant of the community in the litigation, admitted that he did not know si's prenen dites çabogues en lo riu o en la mar. ${ }^{84}$ Finally, the bishop concluded that all the fish caught in Cullera had to pay the tithe of all the fish as it was caught in the sea.

Regarding fisheries and hatcheries, they should have existed more than sources let us know. The existence of a wide net of channels in each one of the different irrigation systems of the kingdom made building structures for catching the fish easy. It seems that most of these were assembled in the right moment of the fishing and due to that there is not written evidence of them. ${ }^{85}$ However, in the major channels like those of the horta of Valencia, more permanent structures existed requiring frequently the authorization of the local council and the payment of a tax for its exploitation. Notwithstanding all these, making a profit of these structures seemed to be guaranteed, since they used to be near the towns, where all kind of food products were highly demanded. Because of that, it is not odd that sometimes the exploitation of these fisheries generated some legal disputes.

That happened with the fishery known Comuns de les Marjals. ${ }^{86}$ Galceran Lluna, a farmer inhabitant of the city of Valencia, had obtained from the Council -and confirmed by the king himself-the establishment of the aforementioned fishery in 1499. One year later, Galceran d'Eixarc — racional, this is, the king's delegate, in the Council of Valencia- claimed to have the rights over the fishery given the establishment conceded by the batle general — the king's administrator in the kingdom. The dispute was resolved by a concord the content of which has not survived, although, despite that, the identity of both actors and the quarrel itself enlightens us about the profits of this type of buildings. Obviously, both Lluna and Eixarc were, at different levels, businessmen, so they had to manage the fishery through labourers or subestablishing truly fishermen in it.

Regarding hatcheries, evidence is quite rare and linked to lords' demesnes. The duke of Gandia, Alfons d'Aragó, named the Elder, had a pond in his country state of el Real, although it is not clear that it was used as a hatchery. ${ }^{87}$ In the next evidence there is no doubt in this respect. On the $14^{\text {th }}$ of April of 1495 the Count of Cocentaina, Joan Roís de Corella, donated his brother Roderic Roís de Corella an

84. "if shads are caught in the river or in the sea". ACV. No. 3632, without folio (10 April 1492).

85. Indeed, some of them consisted on, simply, a net for not letting pass the fish like the mentioned the privilege granted to the owners of a fisher: nobody dares to posar exàrcia alguna de peixcar per spay de xixanta passes entorn axí de perturbar lo exercici de la dita peixquera sots pena de xixanta sous ("introduce any given net for fishing in the sixty passes around nor disturbing the work of the fishery under a fine of sixty shillings"). ACCV. Protocols, No. 23023, without folio (7 August 1500).

86. ACCV. Protocols, No. 23023, without folio (7 August 1500). About Eixarc and his relation to the king see Belenguer Cebrià, Ernest. Fernando el Católico y la ciudad de Valencia. Valencia: Publicacions de la Universitat de València, 2012: 263, 265-269, 273-274, 279-281, 283, 286, 319, 327.

87. ARV. Mestre Racional, No. 9202. Garcia Marsilla, Juan Vicente. “Lujo y previsión. Comer y beber en la corte de los duques reales de Gandia", La alimentación en la Corona de Aragón (siglos XIV-XV), Manuel García Guatas, Elena Piedrafita, Juan Barbacil, coords. Zaragoza: Institución Fernando el Católico, 2013 : 135-149. 


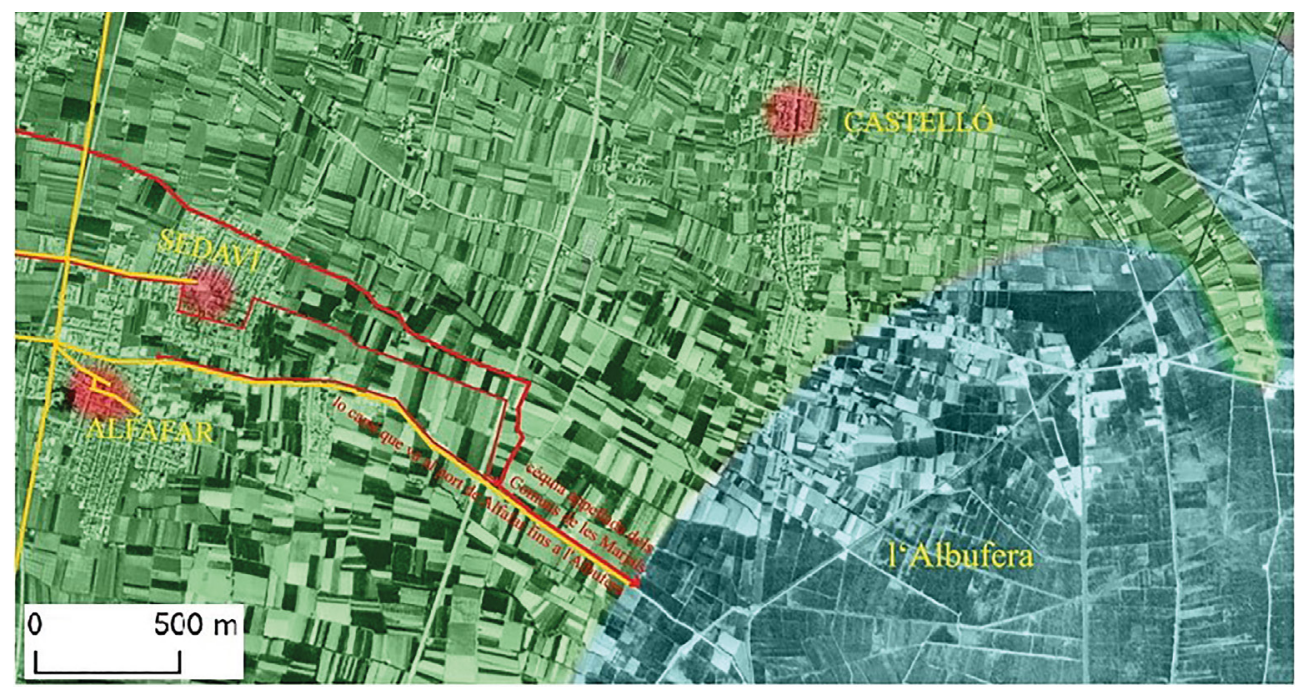

Illustration 1. Fishery known as Comuns de les Marjals. Map provided by the author.

orchard called of the Fish since a hatchery existed just in the middle of the plot. ${ }^{88}$ In both cases, the hatcheries were used to cover the lords' demand of river fish, and therefore as a part of the demesne. Besides this practical use, the ponds were an element of decoration of these idyllic orchards.

One indicator of fish captures could be the tithed collected. The scarcity and chronological dispersion of the evidence of the tithe collected in Valencia make analysing the references difficult. ${ }^{89}$ Furthermore, in the case of fish, we only have the references of the auctioned of the tithe belonging to all the dioceses of Valencia and fifth of the Albufera while for other foods we have the local or regional auctions. As it has been said, fishing used to be a tax-free activity in all the kingdom of Valencia, since James I excluded of the payment of any rent. Fishermen had only to deal with the ecclesiastical tithe for fishing in the Valencian coast and in the lake called l'Albufera. It is supposed that this rent belonged to the Church, but it had been granted to the Crown in the $11^{\text {th }}$ century by the Papacy to promote the conquest. Obviously two hundred years later, clerical authorities did not accept

88. The aforementioned orchard nuncupatum lo ort del Peix was located ad latus menie dicte ville, prout confrontatur, ex una parte, cum menia dicte ville, lo viver o albufera in medio et, ex alia parte, cum domibus Francisci de Leon [...] et cum platea dicta de la Font de Beure. ACCV. Protocols, No. 23818.

89. In the kingdom of Valencia, the tithe was split in three parts. One-third belonged to the king or to those he granted it (terç-delme) and two-thirds to the Bishop. But this general rule has its particularities and nuances according to time, place and products. Díaz de Durana de Urbina, José Ramon; Guinot Rodríguez, Enric. "La dime dans l'Espagne médiévale", La dîme dans l'Europe médiévale et moderne: actes des XXXes Journées Internationales d'Histoire de l'Abbaye de Flaran, 3 et 4 octobre 2008, Roland Viader, dir. Toulouse: Toulouse University Press, 2010: 63-88. 
this agreement without protesting. So, in 1241 James I and the bishop agreed to divide it into three thirds, two of them for the bishop and one (called el terç-delme) for the Crown. For the fishing in the Albufera lake, fishermen had only to pay to the Crown the fifth of their catches for the tithe. The bishop and James I accorded that the Crown would pay 1.000 sous yearly in concept of the tithe belonging to the Church of the fish caught in the Albufera.

Table 1. Quint del peix ("fifth of the fish") from the Albufera (in shillings - sous-) ${ }^{90}$

\begin{tabular}{|c|c|}
\hline Year & Quint del peix \\
\hline 1310 & 12,650 \\
\hline 1311 & 13,600 \\
\hline 1312 & 13,000 \\
\hline 1313 & 15,500 \\
\hline 1314 & 16,000 \\
\hline 1315 & 18,550 \\
\hline $1322-26$ & 20,000 \\
\hline
\end{tabular}

Table 2. Terç-delme del peix ("third-tithe of the fish from the sea") (in shillings - sous-) ${ }^{91}$

\begin{tabular}{|c|c|}
\hline Years & Terç-delme del peix \\
\hline $1381-85$ & 21,000 \\
\hline $1386-90$ & 23,000 \\
\hline $1391-1400$ & 24,350 \\
\hline $1401-15$ & 25,300 \\
\hline $1418-21$ & 32,000 \\
\hline $1422-25$ & 26,000 \\
\hline $1426-29$ & 27,000 \\
\hline
\end{tabular}

90. Muñoz Pomer, Maria Rosa. "El quint del peix de l'Albufera i el terç delme de la mar fins 1431". Afers, 1 (1983), 43-59, particularly 57.

91. Muñoz Pomer, Maria Rosa. «El quint...": 58. 
Despite these lacks mentioned previously, a tendency of the evolution of the fishing tithes can be shaped. Thus, in the near one hundred years passed between 1385 and 1472 the tithe of the sea fish in the dioceses of Valencia experimented a drastic reduction, from 24,000 shillings (sous) to 16,650 . In the short term, the price of the tithe of fish showed certain variability: by 1460 the leasing price was closed in 15.600 shillings (sous) but two years later it decreased to 14,500 , raising again until 16.650 shillings (sous) by 1465 for the next seven years (table 3 ).

Table 3. Tithe of the sea fish in dioceses of Valencia belonging to the bishop (in shillings - sous-)

\begin{tabular}{|c|c|}
\hline Years & Shillings per year \\
\hline $1385^{92}$ & 24,000 \\
\hline $1461-1462^{93}$ & 15,600 \\
\hline $1463-1465^{94}$ & 14,500 \\
\hline $1466-1472^{95}$ & 16,650 \\
\hline
\end{tabular}

\section{From sea to table: supply and consumption of fish}

Regarding fish trade we should differentiate between international and regional commerce and regional. There is more evidence about international commerce since fish was sold in large quantities by wholesalers. Indeed, notaries referred to these merchants specialised in trading fish as tonyiners since tuna was one of the main products they imported. Besides tuna, other they introduced hake and sardines that arrived from Andalucia, Portugal, Galicia and the Bay of Biscay. ${ }^{96}$ Given the demand

92. ACV. No. 4386, f. 50r (6 January 1385).

93. ACV. No. 4387, without folio (6 January 1461).

94. ACV. No. 4387, without folio (20 January 1463).

95. 1466-1468: ACV. No. 4387, without folio (7 January 1466); 1469-1470: ACV. No. 4387, without folio (13 September 1468); 1471-1472: ACV. No. 4387, without folio (7 May 1470).

96. Igual Luis, David. "El tráfico de pescado...": 283, 294-295. Muñoz Pomer, María Rosa; Navarro Espinach, Germán; Igual Luis, David. "El comercio de importación portugués en Valencia, 1487-1488", Os reino ibéricos na idade média: livro de homenagem ao professor doutor Humberto Carlos Baquero Moreno, Luis Adao da Fonseca, Luis Carlos Amaral, Maria Fernanda Ferreira Santos, coords. Porto: Livraria Civilizaçào Editora, 2003: III, 1121-1131. 
of such a big city, these importations became essential to ensure the supply of fish. So, it was not competence for local production. The analysis of the local ordinances shows that, in spite of these importations, the capital attracted fish captures from the different parts of the kingdom.

The evidence of this local and regional trade is more subtle. So, since ice was crucial for keeping fish fresh, a network of exchange existed between coastal places and inner towns that provide fishermen with it. The best of example of this is known as the Cami del peix (Path of fish), that connected the towns of la Vila Joiosa, in the coastal midlands, and Alcoi, in the inner area. So, fishermen walked up with mules and donkeys loaded with fish that they sold in Alcoi but also in the near towns like Cocentaina. Besides the path had different branch lines that passed by Relleu and Penàguila before arriving at Alcoi. Having sold all the fish, fishermen used to go back loaded with ice from the mountains of Mariola. But there is no evidence of this trade in notarial records and in the registries of the court of justice of neither Alcoi nor Cocentaina, the larger towns. This trade went on through the centuries until the last sixty years. ${ }^{97}$

So, given that most of the Valencian rivers were not navigable, inner trade was done with mules. In the coast, transport with boats should be the preferred option although that did not exclude carrying the fish with mules. Thanks to an indirect evidence we know about this trade. Muslim fishermen, or maybe fishmongers, from Calp transported fresh sardines and tuna to the capital of the kingdom with mules. ${ }^{98}$ The sale of fish was one of the most regulated trades in medieval Valencia, as in the rest of Europe. From the capital of the kingdom to any given small town, councilmen efforted to ensure the supply of this foodstuff. The local ordinances were referred about the place for selling the product in order to obtain the appropriate tolls and control the quality of the fish but overall, confirming the arrival of the product. In Valencia, given the size of the city, the places permitted by the Council were different and, depending on each moment, the local authorities licenced even selling the product on the shore. ${ }^{99}$ Given the attraction of the capital, coastal towns and small towns had problems to ensure the supply. It seems that fishermen sold their captures to fishmongers that transferred the product to Valencia. In moments of scarcity even fishers themselves were interested in going to the capital to sell the captures. Councilmen dictated ordinances trying to stop this practice, such as in Castelló de la Plana or in Gandia. ${ }^{100}$ In the town of Dénia the problems forced the local authorities asked the intervention of the count since que.ls pescadors de la

97. Pérez Serrano, Miguel Ángel. “El Camí del peix. Aportaciones para la localización y puesta en valor de una ruta histórica estratégica". Recerques del Museu d'Alcoi, 25 (2016): 127-158.

98. Rubio Vela, Agustín. Epistolari de la València medieval. Valencia: Institut de Filologia Valenciana, 1985: 98-99.

99. Garcia Marsilla, Juan Vicente. La jerarquía...: 104-105.

100. tot pescador o altre qualsevol qui pescara pex a la dita vila aquell haie aportar tot a la plaça e descarregar ans que en casa lo mete ("any fisherman or any given person that fished fish in the aforementioned town has to bring it to the square and unload it before storing at home"). Sánchez Adell, Josep. "La pesca...": 268. Aparisi Romero, Frederic. “La pesca marítima...": 375. 
dita vila haven en nechligència providing the market, causant gran dan e improvessió de la vila ${ }^{101}$ / que cap pescador no gos o presumesqua vendre lo peix a altre pescador tro atant lo mostaçaf ne haja pres a ops de provesió de la vila que serà mester i que el peix que serà mort en les dites mars [de Dénia] per los pescadors sien portats a la plaça de Dénia a vendre e en altre loch no pusquen ésser venuts. ${ }^{102}$

The consumption of fish can be identified through different indicators such as the tithe and tolls collected, the transactions of fish and the archaeological works. Determining the relation between the evolution of the tithe (table 3 ) and the real consumption of fish seems complicated. It could be tempting to bind the increases and decreases in the tithe value with growths and falls in the Valencian population. So, a sluggish rate of demographic growth defined the period between 1375 and 1420 and then, population stagnated or even diminished. However, this decrease had to do with inner migrations and demographic redistribution more than with reduction of population in absolute terms. Indeed, in the long run -from the $14^{\text {th }}$ to the $16^{\text {th }}$ centuries-, the population in medieval Valencia augmented. ${ }^{103}$ Therefore, given that the decrease of the fish tithe value is not corresponded with a fall of population, it is possible that people reduced the consumption of fish in the long $15^{\text {th }}$ century. In any case, it is undoubted that the lessening of the fish tithe value implied a reduction of the fish caught and, therefore, the fishing activity.

Regarding cises (indirect taxes or tolls), the consumption of fish was also burdened which shows it as an essential food with cereals, wine and meat. In the city of Valencia there were six tolls burdened the food consumption among which we find two related to fish, the importation and exportation, which means that not all the fish arrived at Valencia was for consuming there, of dried salted fish. ${ }^{104}$ Fresh fish, therefore, was exempted in the capital of the kingdom. On contrary, in towns, such as Gandia and Castelló de la Plana, both fresh and dried fish were burdened. In both aforementioned towns, the toll of fish -including all types of it - was separated from the rest of them taxes. ${ }^{105}$ It is difficult to explain the reasons for this differentiation could have to do, possibly, with the particular volatility of the fish

101. "the fishermen of this town neglected" "causing great damage and detriment of the town". Colección de documentos...: 69.

102. "no fisherman would not dare to sell the fish to another fisherman before the mostasaf [the market policeman] would have taken as much as it would be needed for supplying the town and that the fish that will be killed in the aforesaid seas [of Dénia] for the fishermen will be taken to the place of Dénia to be sold and it could not be sold in any given place". Colección de documentos...: 69 .

103. Cruselles Gómez, Enrique. "Dinámica demográfica...": 35-36.

104. García Marsilla, Juan Vicente. “Las empresas del fisco. Arrendamiento y gestión privada de los impuestos en el reino medieval de Valencia (siglos XIV y XV)", La fiscalità nell'economia europea. Secc. XIII-XVIII, Simonetta Cavaciocchi, ed. Florence: Firenze University Press, 2008: 851-861, particularly 859-860.

105. Viciano Navarro, Pau. “Ingrés i despesa d'una vila valenciana del Quatrecents. Les finances municipals de Castelló de la Plana (1426-1427)”. Boletín de la Sociedad Castellonense de Cultura, 66 (1990): 635-664, particularly 639; Garcia-Oliver, Ferran. "Memòria fiscal i escalada del deute en una vila valenciana medieval: Gandia a través del seus comptes", El País Valenciano en la Baja Edad Media: Estudios dedicados al profesor Paulino Iradiel, David Igual Luis, Germán Navarro Espinach, eds. Valencia: Publicacions de la Universitat de València, 2018: 137-177. 
toll that depended on season character of both the captures and consumption. The example of Castelló de la Plana shows this. Considering the data from the economic year 1423-1424 as index 100, the fish toll collected showed ups and downs on the next years. Indeed, just on the following year, 1424-1425, it decreased 20,5\%. On contrary, the major tolls displayed a modest tendency of increase, as table 4 shows. This would imply a dwindling of the fish consumption, as I suggest previously for the general tendency of the fish tithe.

Table 4. Tolls from Castelló de la Plana in shillings (sous) ${ }^{106}$

\begin{tabular}{|c|c|c|c|c|}
\hline Economic year & Fish toll & Index 100 & Major tolls & Index 100 \\
\hline $1422-23$ & 2,000 & 83.3 & & \\
\hline $1423-24$ & 2,402 & 100 & 31,500 & 100 \\
\hline $1424-25$ & 1,910 & 79.5 & 30,600 & 97.1 \\
\hline $1425-26$ & 2,600 & 108.2 & 34,000 & 107.9 \\
\hline $1429-30$ & 2,200 & 91.6 & 33,000 & 104.8 \\
\hline $1431-32$ & 2,400 & 99.9 & 33,500 & 106.3 \\
\hline
\end{tabular}

The decrease of the fish consumption seems to be more perceptible in the town of Gandia, which has the Council Accounts records for two economic years, 14051406 and 1435-1436 (table 5). First of all, we can appreciate the decrease of the fish toll collected, passing from 1,520 shillings (sous) by 1405-1406 to 1,100 in 14351436, which meant a marked reduction of near $30 \%$, what is quite significative. In addition to this, we can estimate even hypothetically the household expenses on consumption, accepting that in 1405 the population was around 500 inhabitants and 450 in 1435, and also that all the products burdened were consumed by inhabitants of Gandia exclusively. ${ }^{107}$ So, in 1405-1406 on average each house of Gandia spent 50 shillings (sous) on major tolls whereas it expended 3 shillings (sous) on fish. Thirty years later, the expenditure on fish had been reduced $20 \%$ since on average each house paid 2,4 shillings (sous) for the fish toll while the payment for the major toll reached 52 shillings (sous). In other words, it seems that people reduced the consumption of fish and increased the expenditure in other key products like meat, wine and, most probably, cereals.

\footnotetext{
106. Viciano Navarro, Pau. "Ingrés i despesa...": 639-640.

107. Garcia-Oliver, Ferran. “Memòria fiscal...": 11.
} 
Table 5. Tolls from Gandia in shillings (sous) ${ }^{108}$

\begin{tabular}{|l|c|c|}
\hline & $1405-1406$ & $1435-1436$ \\
\hline $\begin{array}{l}\text { Major tolls } \\
\text { (cereals, cloth, meat and merchandise) }\end{array}$ & 25,000 & 23,500 \\
\hline Fish toll & 1,520 & 1,100 \\
\hline
\end{tabular}

Before concluding this tax considerations, I want to refer about the lessors of all these rents and taxes. Fish tolls, as any council taxes, were, generally speaking, leased by members of the local elite of each town while fish tithe were in hands of merchants of the city of Valencia, given the amount of money it implied for leasing all the diocese of Valencia. Even when the tithe was released in smaller areas than the diocese the lessor was a prominent member of the local community. Joan Gomis, clergyman of the Cathedral of Valencia, ut emptor tunc decime piscium maris diocesus Valentie, resold quarterum vocatum de Calp in annis $M^{\circ}$ CCCC XXI and XXII to Isidor Pérez. ${ }^{109}$ Pérez was inhabitant of Benissa, a coastal village where fishing had to had have an important role in the local economy, like in modern period, although he was not a fisher. So, despite being referred to fish, neither local tolls nor fish tithes were leased by fishermen.

For consuming fish, people had to go to the market, the specific taules (tables) were fish and all the commodities were sold. However, the insistence of local authorities in the obligation of selling the fish in the market place shows that people did not respect them. Indeed, fresh fish used to be sold and resold in the beach itself by fisher's women exempted of municipal taxes. ${ }^{110}$ In Valencia, local regulations forced fishermen to clean the intestine of the large species like tuna in the beach or the harbour before introducing the fish in the city. ${ }^{111}$ It is probably that women helped in this task.

Whereas common people had to go the taules, magnates had direct access to merchants and fishmongers for providing their houses. The first duke of Gandia, Alfons d'Aragó, the Elder, was a good example of the patterns of fish consumption among high nobility during the second half of $14^{\text {th }}$ century and the first decade of the $15^{\text {th }}$. Firstly, for them, fish was essentially a substitute for the meat for the days of abstinence although they consumed during other periods also. Secondly, magnates had a preference for the peix de tall (fish of cut), referring to big species that

\footnotetext{
108. Garcia-Oliver, Ferran. “Memòria fiscal...": 11.

109. Pérez finally paid all the sum in 1425, although this quantity is not referred in the document. ACV. No. 3546, f. 286.

110. Aparisi Romero, Frederic. "La pesca marítima...": 377.

111. Llibre d'establiments i ordenacions...: 377.
} 
need to be cut before cooking them such as conger eel, hake and, overall, tuna. ${ }^{112}$ Thirdly, such preferences did not exclude smaller fishes both for the dukes and their servants like sardines, that were consumed fresh, salted, preserved (escabetx) and smoked. Shellfish was regularly present in their diet. Species varied according to the season, but prawns used to be present in the duke's table regularly while lobster were reserved for special days. Finally, since the table became a metaphor of the social status, the consumption of fish, as any other foodstuffs, did not was strictly related to the place where dukes resided. Indeed, the dukes showed their economic prominence eating fresh fish despite being far from the coast, like in January of 1371 when, staying in Benavarri, in the County of Ribagorça - Catalonia- the duchess asked for sardines, or in the autumn of 1386 when the duke consumed hake from Gandia while he resided in his domains in Castile. ${ }^{113}$

Also, major clergymen, who used to belong to magnate families, contacted directly with fishmongers. So, as it has been mentioned previously, on the $20^{\text {th }}$ of February of 1467 the bishop's butler bought directly from the Bernat Guillem, tonyinerius and congrerius, 18 arroves (187.2 quilos) of conger eel and 2 arroves (20.8 quilos) of hake for the bishop's court. ${ }^{114}$

As other foods, also the consumption of fish was different according to religions, particularly for Jews. For them, according to the kashrut, the fish for consuming had to have fins and scales. Therefore, the conversos were proved to be real Christians consuming species such as eels, conger eels, and moray eels, molluscs, pulps and shellfish. ${ }^{15}$ The lawsuits of the Spanish Inquisition showed how conversos avoided consuming these fishes. So, for instance, Teresa, maid in the house of the converso Galceran Bellvís, a shopkeeper from Xàtiva, declared that her masters, among other Jewish practices, did never eat fatty salt pork and any type of eels. ${ }^{116}$ The consumption of fish used to be regular during all year but particularly in the religious festivities. So, it was the central food for making up the dinner subsequent to the Jew's funeral. In the final, the species consumed in these burial rites depended on the purchasing power of the family, but they varied from sardines to tuna and hake. ${ }^{117}$ Also the fasts

\footnotetext{
112. The prominence of tuna among fish consumed by medieval people may explain the pictures on the walls of the Gates of Quart in the city of Valencia. Aparisi Romero, Frederic. "Beyond defence: art in the towers and gates in the city of Valencia (14th-15th centuries)", Signum lapidarium: estudios sobre gliptografia en Europa, América y Oriente próximo, Raúl Romero Medina, ed. Valencia: Cultiva libros, 2015: 161-174.

113. García Marsilla, Juan Vicente. La taula del senyor duc. Alimentació, gastronomia i etiqueta a la cort dels ducs reials de Gandia. Gandia: Centre d'Estudis I Investigacions Comarcals Alfons el Vell, 2010: 56-67.

114. He paid finally near to one year later. ACCV. Protocols, No. 21873, without folio (14 December 1467).

115. Cantera Montenegro, Enrique. “La carne y el pescado en el sistema alimentario judío en la España medieval". Espacio, Tiempo y Forma. Serie III. Historia Medieval, 16 (2003): 13-51.

116. Barrio Barrio, Juan Antonio. “Los conversos de judío en la ciudad de Xàtiva: creencias y prácticas religioses (1439-1490) a través de la visión del "otro". Medievalismo: Boletín de la Sociedad Española de Estudios Medievales, 23 (2013): 61-99.
}

117. Barrio Barrio, Juan Antonio. “Los conversos...": 84-85. 
of the Yom Kippur and of the Purim - the Queen Ester's fast- used to be finished consuming fish and vegetables instead of meat. ${ }^{118}$

Muslim food system did not have these restrictions about fish, so they went to the market for buying as Christians did. Since domestic buying of fish were not registered neither in notarial books nor in Court of Justice registries - even less in the case of Muslim population, archaeology is the only way to measure the consumption of fish. However, detailed studies based on stable isotope analysis from later medieval sites are quite rare in Valencia. Despite that, with the data available, it has been suggested that Muslim population consumed more fish, particularly marine fresh fish, than Christians, even when those had some many days of abstinence during the year. ${ }^{119}$

\section{Conclusions}

Fishermen never became a collective with economic and political power in medieval Valencia. In the case of the capital of the kingdom, despite they had one of the oldest guilds in the city, it only had competences in fishing matters, without influence over the city council. As any given social group economic differences existed among fishermen, although generally speaking, they belonged to the lower ranks of the local communities. The possession of the boat and nets became the main element of differentiation among them. But, in general, most of fishermen practised farming as a sideline economic activity. The difficulties for making a living seems to be the main reason for the intense mobility that also defined medieval fishermen. This forced some coastal councils to settle fishermen in their towns in order to supply local demand of with fish. Fishermen used to find their wives among the members of the collective although also the lower ranks of the peasantry. Given the general poverty of these families, oral marriage agreements of germania seems to be predominant. However, examples of marriages with dowry has been also given.

Given the Mediterranean environment of Valencia, inland fishing had a secondary role, being basically individual and for autoconsumption. Only in the mouth of the major rivers such as the Guadalaviar, Xúquer, Segura, Millars and Serpis, fishing had some economic importance. So, in medieval Valencia fishing basically meant coastal fishing, although we have some scarce references about hatcheries and fisheries also. The means of production - nets and boats- were not accessible for all fishermen. Indeed, many of them were just labourers in the sea. Others could lease the boat for fishing from their richer neighbours who possessed it as one more of their investments. Generally speaking, a medium size boat cost

\footnotetext{
1 18. Barrio Barrio, Juan Antonio. "Los conversos...": 76.

119. Alexander, Michelle M.; Gerrard, Christopher M.; Gutiérrez, Alejandra; Millard, Andrew R. “Diet, society, and economy in late medieval Spain: stable isotope evidence from Muslims and Christians from Gandia, Valencia". American Journal of Physical Anthropology, 156/2 (2015): 263-273, particularly $272-273$.
} 
between 500 and 800 shillings (sous), although a small one could be bought for 150 shillings (sous).

Fish consumption was defined by an inelastic demand that increased during the periods of abstinence and decrease the rest of the year. Both local catches and international imports supplied the demand, although some nuances can be detected. Whereas the common people consumed, generally speaking, small species, welloff sectors of the society preferred fish of cut like tuna but without relinquishing to the pleasure of sardines and herrings. In the kingdom of Valencia, salting and smoking fish industries did not exist so all catches were sold fresh in the same day or the next, according to local regulations, suppling both inner and coastal towns. On contrary, imports were all salted, smoked or dried fish. Indeed, the capital of the kingdom had to import large quantities of different species of fish such as tuna, hake and sardines. Finally, the consumption of fish also became a symbol for the different religions that existed in Valencia during the Middle Ages. Neither Muslim nor Christian people have restrictions about fish. On contrary, for Jews the fish to be consumed had to have fins and scales. All in all, fish had an essential role as complementary food in the medieval diet, dominated by cereals and meat. Despite this importance and although Valencia was a coastal country, fishing activities did not become a mainstream for the economy of medieval Valencia. 